\title{
The Nuances of Demand in the Analytic Discourse: A Lacanian Perspective
}

"Transference places the subject, with regard to his demand, in a position he occupies only because of his desire" (Lacan, 1958a, p. 531).

Joyce Bacelar Oliveira'

\section{Abstract}

This paper examines the establishment of the analysand's demand in the analytic experience, taking into account his position of desiring subject in the wake of castration. It aims to look into the place of demand in the transference by considering aspects that are relevant to the clinical work, such as the maneuvers of the analyst in the development of one's analysis. On that basis, the author investigates the trajectory of Lacan's elaborations on the concept of transference and its applicability in the psychoanalytic clinic.

KEYWORDS: Demand. Desiring Subject. Transference. Lacan. Psychoanalytic Clinic.

1 Psicanalista. Graduada em Psicologia e em Letras. Mestre em teoria psicanalítica pela UCL (University of London - UK). Membro do Colégio de Psicanálise da Bahia. joycebacelar@gmail.com 


\section{INTRODUCTION}

I focus my research on the place of demand in the transference to investigate the nuances of the demand in the analytic discourse based on the neurotic psychic structure. This is because there is only demand ${ }^{2}$ in neurosis. The neurotic structure is a result of the process of castration. The subject has to undergo castration for the establishment of demand and subsequent desire. Otherwise, demands are reduced to needs only without being affected by the symbolic realm. For instance, psychotics do not experience the process of castration due to the kind of attachment they have with their mothers. In the case of perversion, castration occurs but there is a denegation of it. This means that the establishment of demand does not involve the structure of desire as an effect as well. With this in mind, I would like at this stage to investigate the neurotic structure.

To examine the nuances of demand in the transference is fundamental for understanding the path of desire. However, it is critical to note that it is not really what is demanded that is in question, i.e., the object of the demand. Once the fundamental demand is repressed through the process of castration, what is demanded is simply not what is desired. Rather, demand presents itself through representatives. Lacan defined these representatives as signifiers that correspond to what has undergone repression. That is, demand is represented in a symbolic manner through the chain of the discourse. Thus, it is always demand for something else in a metonymic way in which one signifier of the demand slides to the next one giving a sense of varied possibilities. On that basis, it is crucial to investigate the subject in relation to his demand, bearing in mind that the primal demand is repressed, disguised. The signifiers, which represent this demand, allow the subject to articulate the repressed signifiers in the analytic situation as long as there is access to the unconscious. Nevertheless, what is also of great importance to consider regarding demand is its sexual element in the Oedipus complex. The existence of discourse, through which the subject posits himself, is with respect to his instinctual demand towards his mother and subsequent castration. This involves the subject's effacement by the work of the first repression as a consequence of the Oedipal wishes. Therefore, in the wake of

\footnotetext{
2 Demand for Lacan is what goes beyond a request, in a sense that it is what symbolically is behind a request. For instance, when a patient demands analysis, he is also unconsciously demanding care and love.
} 
castration, there is also the sexual reality of the subject of the unconscious ${ }^{3}$, which is the repressed form of his instinctual wishes towards his mother. Furthermore, there is always something that is left out in the process of repression of those instinctual wishes, remaining unsymbolized, which plays an important role with regards to the drives. Hence, the subject in renouncing his incestuous object in the name of his desire becomes a desiring speaking subject. As a desiring speaking subject, he positions himself with respect to discourse, but there is still something unsymbolized that interferes in the subject's functioning, which is the action of the drives. Therefore, it is essential for the development of one's analysis to situate the subject of the unconscious in relation to his demand and sexual reality, and, in addition, to the manifestation of drives in order to track down his desire.

The analysand displays various kinds of demand in an analysis. The different forms that demand takes throughout the analysis is the tool in the analyst's hands to keep track of the path of desire. Initially, demand presents itself as a request for analysis by the patient. This request is important to get analysis started and delineate what is behind this demand. In other words, what the patient's position is in relation to his desire. However, the crucial move is the establishment of the place of demand in the transference. In what follows, I demonstrate how demand presents itself in the transference, or the engagement of the subject in the analytic discourse, and the importance of the establishment of demand in the course of analysis.

\section{The Concept of Transference in LACAN}

At this point, I think it is important to explore the concept of transference in Lacan. Lacan gave a different approach to it through his clinical and theoretical elaborations on the topic. He used much of Freud's formulations on the concept of transference (Freud, 1911/1913), such as resistances, which are mechanisms of defense unconsciously used by the patient against the development of the treatment, the analyst's position in the session like an opaque mirror, not letting his emotions get involved in the analytic session, and the concept of repetition, in which the patient repeats infantile experiences and feelings through his relationship with the analyst. These are fundamental points to be considered in approaching the theme of

\footnotetext{
${ }^{3}$ Lacan uses in his seminars and writings the terms subject of the unconscious or subject of the signifier to define the structure of the castrated subject. Hence, the formation of unconscious is due to the process of castration. Besides that, the unconscious is formed of signifiers.
} 
transference, and Lacan made good use of them in his elaborations. In the seminar "Transference" (1961), Lacan stated that transference was the automatism of repetition where the patient repeats himself with respect to others in the analytic situation. In doing so, Lacan was willing to introduce transference in a way that he could develop the notion of transferential love. However, the analyst is only an empty mirror, as reflective as possible, in a sense that the subject sees himself in his relationship with others, but the subject should not confuse himself with the place of what is reflected. This is possible owing to the withdrawal of the analyst's ego from the dyadic relationship through his act of silence. In other words, the analyst makes himself invisible for the subject in a sense that his feelings are not part of the analytic setting. Moreover, in his attentive silence, he keeps quiet instead of responding, in a way that he supports the subject's speech rather than allowing the patient to form a new "alienation" 4 in relation to the figure of the psychoanalyst. That is, the analysand should not become identified with the analyst. Hence, silence presupposes interpretation as well as interpretation presupposes presence. Lacan then said:

\begin{abstract}
The point on which there can be centred the question of the function of the analyst as a mirror - it is not the mirror of specular assumption that is in question - I mean as regards the place that he, the analyst, has to hold, even if it is in this mirror that there must be produced the virtual specular image. This virtual image which is here at i prime o, i'(o), here it is and it is indeed in effect what the subject sees in the other, but he only sees it there in so far as he is in a place which is not confused with the place of what is reflected (Lacan, 1961, p. 3).
\end{abstract}

In the seminar "Four Fundamental Concepts of Psychoanalysis" (1964), Lacan further developed the concept of transference giving it a new approach according to his clinical findings. In this seminar, Lacan elaborated that the automatic repetition was no longer related to transference. Transference is essentially resistant, in a sense that the communication of the unconscious is interrupted by the emergence of transferential feelings. Thus, transference is seen as an obstacle for the automatic repetition and results in the closure of the unconscious. Hence, the concept of the automatic repetition developed in the seminar "Transference" (1961), in which Lacan stated that transference was the automatism of repetition where the patient repeats himself with respect to others in the analytic situation, no longer held. This is how Lacan put it:

\footnotetext{
${ }^{4}$ The term alienation in Lacan is used to describe the condition of the subject to recognize himself through the Other. In other words, it is a way to infer the condition of identification of the subject with someone.
} 
"What Freud shows us, from the outset, is that the transference is essentially resistant, Ubertragungswiderstand. The transference is the means by which the communication of the unconscious is interrupted, by which the unconscious closes up again. Far from being the handling over of the powers to the unconscious, the transference is, on the contrary, its closing up" (Lacan, 1977, p. 130).

Here, the concept of the automatic repetition concerns the definition of the unconscious insofar as the subject manifests himself as a stumbling, a fading away, a discontinuity, a vacillation in this repetition through the signifiers. This appears not to be enacted by the transference anymore. However, paradoxically, transference was formulated as an enactment of the sexual reality of the unconscious through tuché of repetition. Lacan borrowed the concept of Tuché from Aristotle ${ }^{5}$ and translated it as the encounter with the real. Tuché of repetition is the encounter with the real because in the symbolic repetition of the unconscious' sexual reality, there is an appeal in the subject's psychic life to an encounter with the initial real. The initial real is the drive, the sexual portion not assimilated by the signifier, left unsymbolized, unrepressed, needing signification. Hence, transference was established on the basis of the sexual real in repetition, instead of the automatic repetition of signifiers. In articulating the sexual real with respect to repetition, Lacan is using Freud's concepts of death drive and repetition formulated in "Beyond the Pleasure Principle" (1920). In these concepts, Freud gave emphasis to the destructive repetition of unbearable past experiences, which caused enjoyment at some point in life, but for a threatening reason related to the Oedipus complex, were suppressed in earlier stages of life. Lacan used Freud's elaborations on the death drive and repetition by also giving attention to the portion of the unconscious' sexual reality and the action of the drives, the unsymbolized part, around it. In the seminar "The Ethics of Psychoanalysis" (1960b), Lacan constructed the concept of jouissance as a symbolic repetition determined by the manifestation of the drives, which is of the real register ${ }^{6}$. Therefore, in the same way as the death drive, jouissance is what goes against life, in a sense that the subject in his symbolic repetition finds satisfaction in displeasure. Lacan then stated:

\footnotetext{
${ }^{5}$ Aristotle uses the concept of Tuché in his search for causes to the question "why?"

${ }^{6}$ The real is a Lacanian concept characterized as what escapes the symbolic, that is, it is what the signifier failed to represent. The drive is situated in relation to the real register because it was left unsymbolized by the action of the signifiers.
} 
The correct concept of repetition must be obtained in another direction, which we cannot confuse with the effects of the transference taken as a whole. Our next problem, when we approach the function of transference, will be to grasp how the transference may lead us to the heart of repetition. That is why it is necessary to ground repetition first of all in the very split that occurs in the subject in relation to the encounter. The split constitutes the characteristic dimension of analytic discovery and experience; it enables us to apprehend the real, in its dialectical effects, as originally unwelcome. It is precisely through this that the real finds itself, in the subject, to a very great degree the accomplice of the drive - which we shall come to last, because only by following this way will we be able to conceive from what it returns (Lacan, 1964a, p. 69).

Still, the concept of transference further developed by Lacan in the seminar "Four Fundamental Concepts of Psychoanalysis" (1964a) appears to be paradoxical. This is due to the fact that transference can at the same time be responsible for setting up resistances - meaning the closure of the unconscious - and be important for its opening. Thus, the role of the psychoanalyst in the transference deserves special attention in the course of one's analysis. I further elaborate on that below.

\section{How Demand Is InStituted In THE TRANSFERENCE}

The establishment of demand in the transference takes place when the desire of the analyst to lead one's analysis is operating. For Lacan, the desire of the analyst is crucial for demand to be instituted, that is, for the engagement of the analysand in the analytic discourse. Once the analysand attributes knowledge to the psychoanalyst and ascribes him as "subject supposed to know" about his sufferings, the analyst occupies the place of the Other ${ }^{8}$ for the analysand. Besides, when the analysand places the analyst as the Other, he is also creating hypotheses regarding the position that the analyst occupies, leading the patient to idealize his analyst. Therefore, the analyst initially is idealized by the analysand, creating a tension in the analysis, an impasse due to the establishment of the patient's subordination to the analyst. This results in impediment for the flow of free associations and development of the analytic discourse. It is worth highlighting that the very first demand that is instituted in the transference is fundamental for the structuring and establishment of the analysis. However, this demand needs to be transformed during the analysis, otherwise the analyst will always be the Other for the patient, not allowing the progress of the analytic

\footnotetext{
${ }^{7}$ Subject Supposed to Know is a Lacanian concept used to designate the place that the analyst occupies at the beginning of one's analysis.

${ }^{8}$ The big Other is a concept that Lacan developed to represent the place designated by a subjective authority in the subject's life.
} 
experience. This means, the subject will get stuck on a new alienation in relation to the analyst, which is to become identified with the analyst as it has already happened with the Other as a consequence of castration. In doing so, the patient will unconsciously find ways to boycott his analysis, such as censuring his speech and, consequently, not permitting the unconscious material to come up during the analytic sessions, making up stories, being late or cancelling the sessions. The important step to be taken by the analyst is to assume the reverse place of the one he has been designated by the analysand.

In the seminar "The Other Side of Psychoanalysis" (1970), Lacan formulated the place of "make-believe object a cause of desire" within the analyst's discourse to function as the reversal to the role of idealization. The "object a cause of desire" is equivalent to the "lost object" from the process of castration. The "lost object" is what became of the "imaginary phallus" ("object a of desire") that the child tried to be for his mother in the Oedipus complex. Besides that, the "object a cause of desire" has a metonymic function with respect to desire. This sets desire in motion once the "object a of desire" is lost. In occupying symbolically the place of "make-believe object a cause of desire", the analyst presents the "lost object" in order to cause the patient's desire, instead of being the figure to be identified with. It is important to bear in mind that if the object is forever lost, what can be obtained from its reappearance in the analyst's discourse is the lack itself. Thus, the place of "object a cause of desire" has the same function as that of the lack of the subject due to the castration: the one that determines the division of the subject. This division, which is also represented by a lack, takes place when the subject goes through castration. That is, the subject becomes a divided subject and no longer the object of the mother's desire. The lack or division from the process of castration is essential for the constitution of the desiring subject. Therefore, the analyst presents symbolically the lack of his being to the analysand in order to give way to the analysand's speech. In this way, the analyst confronts the divided subject with his own desire, making him realize that he is the one, not the analyst, who is supposed to know about himself as Lacan (1964a) stated: "what I have depicted here by means of the rim comes back on to the plane constituted by the locus of the Other, from the place where the subject, realizing himself in his speech, is instituted at the level of the subject who is supposed to know" (LACAN, 1970 p. 271).

To examine further the status of the place of demand in the transference is crucial to look closely at the analyst's discourse. The discourse of the analyst is the 
discourse that provokes the patient's discourse once the analyst disinvests himself of the place of the Other. This means, as an effect of the analyst's discourse, the truth of the subject emerges in the sessions as he tries to work through the unconscious material around the manifestation of the drives, the unsymbolized part. Lacan (1970) then remarked on the importance of the analyst's discourse in the development of one's analysis: "It's another question to ask what the analyst is taking the place of when he unleashes the movement that invests the subject supposed to know - a subject who, by being recognized as such, is, with regard to the analyst, ready in advance for what is called transference... The analyst makes himself the cause of the analysand's desire" (LACAN, 1970 p. 38).

In occupying the place of "object a cause of desire", the analyst is maneuvering the transference and, consequently, situating the analysand in his own division. Hence, instead of the analyst being in the place of the master for the patient, he removes himself from this place of power to cause the desire of the subject. As a result of this operation, the demand of the analysand towards the analyst modifies in the transferential relationship, permitting the opening of the unconscious. This implies a subsequent connection between the patient's demands and his sexual reality linked to the manifestation of the drives. It is a fundamental modification that should take place in analysis in order to give way to the analysand's subjectivity, thus desiring subject, instead of letting the analysand remain attached to his rationality.

\section{Demands of the Analysand}

Demand takes up diverse forms in the course of analysis. The very first demand is for cure even if the analysand is not aware of it. For instance, the analysand may want to be in analysis due to his analytic training. However, the analysand still seeks analysis because he is not well despite the fact that he may not be conscious of it. Thus, the analysis is for the analysand a way out of his pain and he sees the analyst as the one who knows about his difficulties and can resolve them. On the other hand, the analysand is not aware that satisfaction does not always involve happiness, or pain may unconsciously bring satisfaction of some sort. Neither does he know the extent to which he really desires to get rid of the suffering as he has become attached to it as part of his life. "The first ambivalence proper to every demand is that in every demand there is also implied that the subject does not want it to be satisfied, aims in itself at 
the safeguarding of desire, testifies to the blind presence of the unnamed, blind desire" (LACAN, 1961, p. 6).

Once the analysand places the analyst in the position of "subject supposed to know", which is the place of the Other who has a subjective authority over the subject, demand begins to take the form of demand for love. The subject wants to be loved, keeping the place of the analyst as the one who knows about him and can take care of him. However, this idealized place makes room for all resistances that the patient unconsciously sets up in the transference, not allowing the opening of the unconscious and access to the truth of the subject. Lacan (1964a) then said:

\begin{abstract}
What emerges in the transference effect is opposed to revelation. Love intervenes in its function, revealed here as essential, in its function as deception. Love, no doubt, is a transference effect, but it is its resistance side. We are linked together in awaiting this transference effect in order to be able to interpret, and at the same time, we know that it closes the subject off from the effect of our interpretation. The alienation effect, in which is articulated, in the relation of the subject to the Other, the effect that we are, is here absolutely manifest (p. 253).
\end{abstract}

The only way out is to change the form of demand through a maneuver of the analyst. It is from this idealization that the analyst has to fall as mentioned above. The analyst has to remove himself from this idealized position in order to occupy the place of "object a cause of desire". In this way, he gives space for the analysand to utter his demands around his sexual reality. In doing so, the analysand makes a connection between his demands and sexual reality, bringing out the unconscious material linked to the action of the drives. Otherwise, the analysand gets arrested in his censorship towards the Other, not permitting himself to work through the unconscious material and symbolize the manifestation of the drives.

Yet, the analyst should handle all demands that take form in the discourse of the patient throughout the analysis. Lacan stated that as the analysis goes on, the analyst copes with all articulations of the subject's demand, especially those ones associated with the sexual reality. However, the psychoanalyst must deal with them only from his place in the transference, which is, according to Lacan, that of the dummy. That is, the analyst conducts the analysis in such an impassive way that he is dispossessed of his own feelings, playing the dead in his relationship with the analysand. In doing so, the analyst plays the "game" in order to activate the analytic discourse, but he does not play with his own feelings. That is, "what is certain is that the analyst's feelings have only one possible place in the game, that of the dummy; 
and that if the dummy is revived the game will proceed without anyone knowing who is leading it" (LACAN, 1958a, p. 493).

\section{Demand, THE SignifieR}

Lacan borrowed the concept of signifier from the linguist Ferdinand Saussure (1911) and related it to a concept that Freud had formulated and used in his writings: "ideational representatives"9. For Freud, ideational representatives are the unconscious expressions of the instinctual demand of the child towards his mother. Thus, Lacan used the concept of signifier in the same way Freud did with the concept of the ideational representatives.

The instinctual demand of the child towards his mother (Other) is an effect of the demand of the child's mother. This deserves special attention in understanding the appearance of the signifier that has been repressed and represents the instinctual demand of the child. "Here the subject designates himself in the evacuated object as such. Here is, as I might say, the zero point of desire. It reposes entirely on the effect of the demand of the Other. The Other decides about it, and indeed it is here that we find the root of this dependency of the neurotic" (LACAN, 1961, p. 7).

The very first demand in one's life is towards the mother. This demand initially takes the shape of needs to be fulfilled in the course of one's development. But these needs soon become proper demands once they are affected by the symbols that surround the subject in the environment. For instance, once the child seeks food not only as a fulfillment of his needs but also as an assurance that he is cared and loved, he starts to symbolize presences and absences of the mother as well. Since the mother first occupies the place of the Other in the relationship with the child, the child is willing to be the sole object of the mother's desire. It is important to bear in mind that the child's demand is established by the mother's position in their relationship. This means that the child's demand is caused by the mother's demand with regards to the child. Hence, the mother actively participates in this symbiotic relationship with the child, displaying demands towards him and permitting this enjoyment (jouissance) to take place. In the seminar "Identification" (1962), Lacan stated that it is through the dependency on the demand of the Other that the child tries to found his desire. That is, it is through the dependency on the demand of the mother, which is an unconscious

${ }^{9}$ Ideational representatives are also known as the representations of the ideas of things, or even symbolic representation along Freud's work.

194 Psicanálise \& Barroco em revista | v.16, n. 01 | julho de 2018 
demand to be supplemented as she is "not-whole"10, that the child constitutes the "object a of desire", the imaginary phallus, for his mother. However, this jouissance between the mother and the child has to be interdicted by the law that governs the rules in society. The Paternal Metaphor also known as The Name of The Father ${ }^{11}$ might be substantiated by the father as well as other means that symbolically provide the functioning of society, such as the work of the mother, an older sibling, the mother's partner. The Paternal Metaphor is going to mediate the law, interdicting the jouissance between the child and the mother. Once the child is not allowed to be the object of the mother's desire, the signifier that represents the paternal metaphor is going to substitute the signifier of the mother's desire, the imaginary phallus. Thus, the signifier of the primal demand, which is the demand to be the mother's object of desire, is also going to be repressed. Let us note that Lacan called attention to the position of demand in the unconscious as an effect of castration:

We can reconstitute it, rediscover what I will call the labyrinthic pathways on
which are marked the essential fact of the position that the subject has taken
in this reference, in this relationship which is structural for him, between desire
and demand. And if the maintaining of the incestuous position in the
unconscious is something which has a meaning, and which effectively has
consequences, which are destructive in different ways of manifestations of
desire, of the accomplishment of desire of the subject, it is precisely for no
other reason than the following: it is that what the so-called incestuous position
preserves somewhere in the unconscious, is precisely this position of demand
(LACAN, 1959, p. 107).

That is to say that the repression of the primal demand gives rise to the signifier that will represent this demand. That is, the signifier will be articulated in different ways through the form of demand for love. Demand for love is how the subject conceives of his demand because he is willing to be loved. In other words, demand for love masks the presence of the sexual reality since it is kept apart as if it is a menace for the subject. This happens due to the censorship the subject suffers in the wake of castration. Nevertheless, the result of repression is the subject's disjunction and conjunction with the "lost object". Hence, the divided subject in a hesitant way wants

\footnotetext{
${ }^{10}$ Lacan elaborated the concept of woman as a "not-whole" in his seminar On Feminine Sexuality: The Limits of Love and Knowledge, Encore (1973), in order to explain the woman's incompleteness as a subject who is deprived of the sexual male organ. Hence, according to Lacan, woman is "not-whole" insofar as she has the choice of positing herself in the phallic function or not being part of it, whereas man as a "whole" acquires his inscription through the phallic function. That is to say that the phallic function does not depend entirely on the erectile organ, it can also be obtained through the subject's different ways of pursuing jouissance.

11 The Paternal Metaphor or The Name of The Father are Lacanian concepts that represent the rules of society.
} 
to keep the place of object of the Other's desire that was experienced through the effects of the demand of the mother in the Oedipus complex. According to Lacan, these effects are at the crux of the power of the treatment because they delineate the path of desire, which is the path taken by the desiring subject after castration. In his article "The Direction of the Treatment and the Principles of Its Power" (Écrits, 1958), Lacan explains the importance to examine the place of desire in relation to the effects of demand as the only way to keep track of one's desire.

\section{The Importance of the Place of Demand in the Transference and the ACCESS TO THE UNCONSCIOUS}

The subject's demand is fundamental for the development of the analysis. If there is no demand, the work of psychoanalysis will be restricted to the analysis and strength of the analysand's ego as it happens in the analysis of psychotics. In psychoses there is no way for demand to be established once psychotics have not gone through the process of castration. As mentioned earlier, for the establishment of demand and subsequent desire, the subject has to undergo castration, without which, demands are reduced to needs only, without being affected by the symbolic realm. Moreover, as a consequence, the individual does not become a desiring subject, that is, he refuses subjectivity. It means that psychotics did not renounce the place of object of the mother's desire in the name of his desire, which is not dependent on the mother's demand. "The subject at a moment, it is said, and this is how Mr. Jones expresses it, has to choose between his incestuous object and his sex. If he wants to preserve one he must renounce the other. I would say that what he has to choose at this initial moment is between his demand and his desire"(LACAN, 1959, p. 108).

That is to say that the access to one's desire is possible in the analytic situation because of the unconscious formation. This involves the repression of the signifiers of demand and its sexual reality as a result of castration.

Nevertheless, the process of castration is responsible for the subject of the unconscious split into the signifiers of demand and sexual reality. This is due to the subject's separation and alienation in relation to the "lost object". Hence, the paradox presented above regarding the closure and opening of the unconscious in the transference is going to be elucidated from the understanding of the division of the unconscious into the automatic repetition of signifiers and the presentation of sexual 
reality. This division is shown in the matheme for the fantasy of Lacan $(\$<>a) .{ }^{12}$ The matheme for the fantasy, which is further elucidated in Lacan's seminar "The Object of Psychoanalysis" (1966a), demonstrates the separation and alienation of the barred or divided subject in relation to the "lost object". To recapitulate, the barred or divided subject is a consequence of castration, which in psychoanalysis consists in the operation of interdiction that the child suffers, preventing him to be the object of his mother's desire. Whereas, the "lost object" represents the object of the mother's desire, the imaginary phallus that the child tried to be for his mother. Hence, the matheme for the fantasy presents the subject of the unconscious in relation to the "lost object", "object a", trying to keep the place experienced through the effects of the demand of the mother. But, the divided subject is in disjunction and conjunction with his sexual reality without coming to terms with his desire.

To further unfold the psychic life of the subject, it is important to return to the concept of repetition in the transference, which Lacan elaborated as the concept of Tuché of repetition in his seminar "Four Fundamental Concepts of Psychoanalysis" (1964a). Lacan refers the concept of tuché of repetition to the concept of traumatism in Freud, which appears at the level of the sexual as it is shown in the primal scene in the "Wolf Man" (FREUD, 1918). That is, it is a model of trauma as a deferred effect of a sexual memory trace from childhood. Besides that, the place of the real, the unsymbolized that was not assimilated by the action of the signifier, goes from trauma to fantasy. Lacan stated that the fantasy acts as a screen that conceals what is determinant in the function of repetition. However, the signifying repetition appears to be determined by the traumatism as real due to the fact that there is a psychic appeal to an encounter with the initial real, the real of traumatism. Thus, the work of analysis needs to unravel the traumatic scene or event in the repetition of the fantasy of the subject in order to relate it to the unconscious material.

That is to say that Lacan's investigations based on Freud's findings on the concept of transference and repetition, led Lacan to formulate that transference is the enactment of the sexual reality of the unconscious through tuché of repetition. This is possible due to the opening of the unconscious when the analyst occupies the place of "object a cause of desire" for the analysand, allowing the patient to tear down the walls of censorship, enact his fantasies and repeat himself in the analytic discourse. In

12 Matheme is the symbolism that Lacan constructed for thinking the psychoanalytic experience.

Psicanálise \& Barroco em revista | v.16, n. 01 | julho de 2018 
doing so, the sexual reality of the unconscious becomes accessible, permitting its relation to the demand. This connection between demand and sexual reality confronts the unconscious material, the repressed signifiers. In addition, it becomes possible to relate the repressed signifiers to the real as traumatism, the action of the drives, in order to translate them into the path of desire. Therefore, there is another split besides the division of the unconscious into the automatic repetition of signifiers and the presentation of sexual reality. It is the split in the repetition into automaton and tuché. That is, repetition is divided into the automatic repetition of signifiers that are the unconscious part and the signifying repetition determined by the action of the drives, which is of the real register. Hence, instead of separating the unconscious from drives: the subject, as he appears in the field of the Other, which is the subject of the signifier, from the subject, in the field of the drive, the real of traumatism - automaton from tuché - the analytic discourse will bring them together, making the access to desire possible. This is how Lacan put it:

If I have spoken to you of the unconscious as of something that opens and closes, it is because its essence is to mark that time by which, from the fact of being born with the signifier, the subject is born divided. The subject is this emergence which, just before, as subject, was nothing, but which, having scarcely appeared, solidifies into a signifier.

On this conjunction between the subject in the field of the drive and the subject as he appears in the field of the Other, on this effort to join oneself together, depends the fact that there is a support for the ganze sexualstrebung. There is no other. Only there is the relation of the sexes represented at the level of the unconscious (LACAN, 1964a, p. 199).

Hence, the unconscious is split into automaton, automatic repetition of signifiers, and the presentation of the sexual reality. Transference is conceived as a means that gives access to the unconscious, connecting the signifiers of demand with the signifiers of sexual reality. Besides that, transference brings together the repetition of the repressed signifiers and the symbolic repetition determined by the manifestation of the drives to the forefront in order to confront the reality of the unconscious. "The experience of the subject is thus brought back to the plane at which, from the reality of the unconscious, the drive may be made present" (LACAN, 1964a, p. 274). 


\section{Transference in the Imaginary, Symbolic and Real Orders, AND the Particularization Of Demand}

"Transference tends to be exercised in the direction of the closing up of the unconscious. I have already explained to you how it works, by referring to it the narcissistic relation by which the subject becomes an object worthy of love" (LACAN, 1964a, p. 267). That is to say that transference initially presents itself in the imaginary dimension, which is the realm of the sensorial perceptions. It is through the imaginary register that the analysand establishes a narcissistic relationship with the analyst. The analysand posits himself in the analytic sessions around his own ego and its perfections. That is, the subject makes his way to become an object worthy of love according to Lacan. Moreover, what comes to the forefront in the analysis is the ego of the analysand. This is deception and impediment for the work of analysis.

Dealing with the ego of the analysand does not imply analysis, it only means that the analysis has been reduced to ego psychology ${ }^{13}$. In his article "Presentation on Transference" (Écrits, 1951), Lacan defined transference in the imaginary order as a moment of stagnation in the analytic experience. This is because the access to the unconscious material is censored by the ego of the analysand in the form of rationalizations. These rationalizations appear in the way the patient perceives himself as a victim of the circumstances. That is, a "fiction" that the analysand creates from his neurosis as it is shown in the "Family Romances" (FREUD, 1909), in which the patient tries to place himself in a plot to form the basis of his history. Hence, the imaginary convictions of the neurotic should be destabilized in the analytic experience in order to give place to the subjectivity of the analysand.

Once the analyst occupies the place of the Other, or the place of "subject supposed to know" ascribed by the analysand, some signifiers will come to the fore through the free associations as a manifestation of the unconscious in the symbolic realm. Furthermore, demand will be for love and the symbolic relationship will be established. However, the signifiers by themselves will only be underneath the signifying articulation of the patient's discourse without any access to the unconscious' sexual reality. This is due to the idealized place the analyst occupies in the transference. Besides, the manifestation of the unconscious only occurs in intervals as

${ }^{13}$ Ego psychology is the school that deals with the ego developments and its interactions with the external world. 
the subject manifests himself through dreams, slips of tongues, witticisms and symptoms in this repetition through the signifiers. This makes the unconscious appearance discontinued without being enacted by the transference. In other words, the unconscious closes itself as the effect of transference, because the analyst has become idealized by the analysand when he was ascribed the place of "subject supposed to know". The psychoanalyst has to maneuver the transference analytically in order to allow the opening of the unconscious, access to the signifiers of demand together with the signifiers of sexual reality, and the relation to the manifestation of drives. Lacan then remarked on how the subject should see himself caused as a lack by the manipulation of the transference: "I mean that the operation and manipulation of the transference are to be regulated in a way that maintains a distance between the point at which the subject sees himself as lovable - and that other point at which the subject sees himself caused as a lack by a, and where a fills the gap constituted by the inaugural division of the subject" (LACAN, 1964a, p. 270).

For this to happen, the analyst needs to abandon the place of idealization and become symbolically the "object a cause of desire" of the analysand, in order to confront the subject with his own desire. In doing so, the manifestation of the real in the symbolic repetition will be related to the emergence of signifiers. Hence, the demand of the subject will be particularized when his unconscious opens as an effect of the analyst's discourse, permitting the associations of the signifiers of demand with the signifiers of the sexual reality coupled with the action of the drives of the real register. This maneuver taken by the analyst is important to bring the signifiers of the unconscious, which represent demand and sexual reality, together with the manifestation of the drives of the real dimension. That is,

In order to give you formulae-reference points, I will say if transference is that which separates demand from drive, the analyst's desire is that which brings it back. And in this way, it isolates the a, places it at the greatest possible distance from the I that he, the analyst, is called upon by the subject to embody. It is from this idealization that the analyst has to fall in order to be the support of the separating a, in so far as his desire allows him, in an upsidedown hypnosis, to embody the hypnotized patient (Lacan, 1964a, p. 273).

\section{The Desire of the Analyst}

To understand the place of demand in the transference is also important to examine the desire of the analyst. The concept of the analyst's desire is crucial in the work of analysis and has been theorized by Lacan in different times. In the seminar 
"Four Fundamental Concepts of Psychoanalysis" (1964a), Lacan stated that the analyst's desire is a desire to obtain absolute difference. Lacan meant that it is a desire that makes the patient confront with his primary signifier, in which he is subjected as a consequence of castration. That is, the analysand is subjected to the primary signifier, which is the signifier of the phallus that the "lost object" became as a result of castration. Since the subject unconsciously wants to keep the place of object of the Other's desire experienced in the Oedipus complex, he is, in this way, subjected to the primary signifier. Hence, the analyst's desire is to confront the subject in this place of subjection that he is embodied in relation to the "lost object" in order to bring out his own desire: "The analyst's desire is not a pure desire. It is a desire to obtain absolute difference, a desire which intervenes when, confronted with the primary signifier, the subject is, for the first time, in a position to subject himself to it. There only may the signification of limitless love emerge, because it is outside the limits of the law, where alone it may live" (LACAN, 1964a, p. 276).

In the seminar "The Other Side of Psychoanalysis" (1970), the analyst's desire is defined as desire to know. The desire to know of the analyst is with regards to the master signifiers of the subject that come from the Other. Master signifiers correspond to single traits or specific characteristics of the Other, the one responsible to mediate the rules of society to the subject, and from whom the subject became identified with. Hence, in this seminar Lacan used a matheme to demonstrate the dynamics of the signifiers in the analyst's discourse and how the analyst operates with respect to the patient. Thus, the analyst symbolically occupies the place of "object a cause of desire" in his discourse. This place concerns the position through which the analyst supports the speech of the analysand in a way that the analysand is able to produce master signifiers. Hence, the master signifiers of the subject should come to the fore in the analytic discourse through the articulations of the demands of the patient in the transference. Besides that, the psychoanalyst, through his interpretations, gives sense to the unconscious content and action of the drives that come up in the sessions in the signifying chain of discourse of the analysand in order to track down the subject's desire. This is how Lacan formulated the position of the analyst: 
Concerning the position called that of the analyst - in cases that are moreover improbable, for is there even a single analyst? Who knows? But one can raise it theoretically - it is the object a itself that comes to the place of the command. It's as identical with the object a, that is to say with what presents itself for the subject as cause of desire, that the psychoanalyst offers himself as the end point for this insane operation, a psychoanalysis, insofar as it sets out on the trace left by the desire to know (LACAN, 1970, p. 106).

Hence, the place of the "object a cause of desire" is part of the analyst's discourse that was elaborated by Lacan in 1970. This discourse consists of four elements: ${ }^{14}$ a, object cause of desire; S2, knowledge; $\$$, the barred or divided subject and S1, the master signifier. Their positions above and below the bar on either side of the diagram represent four different functions: the agent, the truth, the other and the production respectively. In this discourse, the analyst is the agent and accepts to be, symbolically, the "object a cause of desire" of the analysand in order to situate the analysand's in his own division while subject, pushing the analysand to produce master signifiers. The function of truth, which is beneath the analyst in the diagram, is fed through the analysand's production of master signifiers. This function of production is under the function of the other, which is the analysand in the diagram. Thus, this discourse is the maneuver that Lacan elaborated aiming at the removal of the analyst from the place of identification, permitting the opening of the unconscious of the analysand, access to the signifiers and subsequent relation to the action of the drives.

I believe that the concept of desire of the analyst that Lacan developed in 1964 as well as the other one he elaborated in 1970 complement one another. In a sense that the subject should be confronted in his place of subjection to the primary signifier, the "lost object", as well as in his place of subjection to the master signifiers, the Other's desire. This confrontation is the means for the subject to get to know what he is in relation to his demand in the transference, coming to terms with his own desire.

\title{
The AdVent of the SUBJect of the UnConscious in ANALysis
}

\begin{abstract}
"Interpretation is not open to all meanings. It is not just any interpretation. It is a significant interpretation, one that must not be missed. This does not mean that it is not this signification that is essential to the advent of the subject. What is essential is that he should see, beyond this signification, to what signifier to what irreducible, traumatic, non-meaning - he is, as subject, subjected" (LACAN, 1964a, p. 250).
\end{abstract}

14 The matheme of the discourse of the analyst: a/S2 - \$/S1. 
Interpretation has a significant role in unfolding the psychoanalytic discourse and it is an important tool in the analyst's hands to confront the subject in his place of desiring subject. The advent of the subject is an operation that takes place in the analytic experience, in a sense that the subject should assume his own desiring position with regards to others. This means that the subject should unleash himself from the place of subjection to the Other's desire. The advent of the subject of the unconscious in analysis is essential to desalienate ${ }^{15}$ the subject from the Other's desire. It is a move from being object of the Other's desire to be subject of his own desire. Even though the existence of the subject is due to the Other's desire, the subject also posits himself with respect to his own existence once he assumes a position with respect to the "lost object". The subject's emergence is indeed caused by the Other's desire when he gains access to the signifier of the Other's desire through the paternal metaphor. But since the subject becomes identified with the "lost object" as a consequence of castration, he also subjectifies his existence. In other words, the subject symbolizes his relation of separation and alienation to the "lost object" as it is shown in matheme of the fantasy $(\$<>$ a). Here, the subject is divided owing to the repression of the first signifier (signifier of the phallus) and, subsequently, separated and alienated in relation to the "lost object". However, this identification of the subject with the "lost object" does not allow him to implicate himself in his own discourse as a desiring subject once he still situates himself as object of the Other's desire. Lacan (1959) then stated that:

\begin{abstract}
It is between the avatars of his demand and what these avatars have made him become, and on the other hand this exigency for recognition by the Other which can be called exigency for love on this occasion, that there is situated a horizon of being for the subject of whom there is question, namely of knowing whether the subject can reach it or not. It is in this interval, in this gap that there is situated an experience which is that of desire, which is first of all apprehended as being that of desire of the Other, and within which the subject has to situate his own desire. His own desire as such cannot be situate elsewhere than in this space (LACAN, 1959, p. 14).
\end{abstract}

Hence, the analytic maneuver should take place positing the subject as responsible for his actions. This leads the subject to assume his own cause with respect to the Other's desire. That is, the subject should subjectify the sexual reality and traumatic cause of his own advent as subject. Then, he may occupy the place

${ }^{15}$ Whereas the term alienation is used in Lacan to describe the condition of the subject to recognize himself through the Other, desalienation is used to infer the process of independence from the Other's desire. 
where the Other's desire had been. In assuming his own cause, the subject adopts a new position with respect to the Other as language and the Other as desire once both language and desire of the subject come from the Other. This involves the subject becoming able to say "I", for instance: "I did", "I was", "I am" rather than "It happened to me", "Someone did it to me", "He/She is".

"I must come into being in analysis, where the unconscious was (to be) itself" (LACAN, 1960a, p. 691). When Lacan said "I" must come into being in analysis, where the unconscious was itself, he was in a way quoting Freud's motto (1933) wo es war, soll Ich werden (where it was, I shall become). Lacan related it to the truth that should come up when the subject is confronted with his unconscious desire. In other words, there where it was, the Other's discourse was, the subject must say "l" implicating himself in his desiring position. Thus, the analysand should also situate himself in relation to his demands in the transference. That is, what his position is as a desiring subject in relation to his demands in the analytic experience.

\section{For Demand to be Instituted, the Analytic Setting is Crucial}

"I said somewhere that an analyst has to pay something if he is to play his role. He pays in words, in his interpretations. He pays with his person to the extent that through the transference he is literally dispossessed" (LACAN, 1960b, p. 357). That is, the analyst pays with his desire. The desire of the analyst to operate an analysis is crucial for the establishment of demand in the transference.

Now, considering the analytic setting, in what extent is it important in operating an analysis? Could an analyst lead an analysis on the phone or skype, for instance? Maybe the answer would be: is it possible to sustain any kind of relationship this way? Possibly, not. But, taking into account only the relationship between the analyst and the analysand, what is the impediment for the development of an analysis outside the consulting room? Firstly, the establishment of transference initially occurs in the imaginary dimension, in which the analysand's ego is in the forefront together with all its defenses. If the analysis takes places on the phone, it is probably all about the ego of the analysand and its defenses once there is no private space to move forward and tackle the analysand's unconscious elements. Besides, the silence of the analyst does not suppose presence, neither interpretation since it is all about the interaction on the phone. Naturally, voices are superimposed in this kind of situation due to the lack of setting, which also implies the absence of bodies. If interpretation is the analyst's only 
job, the analyst remains the "subject supposed to know". That is, the analyst's speech is privileged over the analysand's when it should be the other way round. Secondly, demand presents itself more as a request, being sort of affected by the transference in the symbolic register. This is because the place that the analyst occupies for the analysand eventually becomes that either of the master, the one who has got the power, or that of the university, the one who has got the knowledge, according to Lacan's discourses of the master and the university (1970). That is, the analyst becomes idealized by the analysand, without the possibility of occupying the place of "object a cause of desire" as there is no environment for the analyst's maneuvers. Thus, the analyst is unable to place the analysand as subject supposed to know about his own symptom if there is no setting for the withdrawal of the analyst's ego. This is because the analyst is engaged in the dyadic relationship through one only way of intervention, which is his voice. Furthemore, demand is not really instituted in order to particularize later on. In other words, demand may not be enacted in the transference in conjunction with the sexual reality once there is no space for the patient to overcome his censorship. Hence, the relationship is reduced to problems solving without dealing with the unconscious material. Thirdly, persecutory feelings, which are part of the imaginary realm, can be developed since there is no analytic setting. The analysand might wonder if there is anybody else listening to what he says, keeping the access to the unconscious closed.

Therefore, the relationship between the analyst and analysand probably fluctuates between the imaginary and symbolic dimensions. In a sense that there is less possibility for the signifiers of demand and sexual reality to emerge coupled with the manifestation of drives of the real realm. Besides, neither the desire of the analyst nor the desire of the analysand will operate once the relationship has been reduced to resolve problems, instead of the constitution of desire in both parts. Lacan argued that: "what the analyst has to give, unlike the partner in the act of love, is something that even the most beautiful bride in the world cannot outmatch, that is to say, what he has. And what he has is nothing other than his desire, like that of the analysand, with the difference that it is an experienced desire" (LACAN, 1960b, p. 369).

Hence, as we can see, there are many aspects involved in the consulting room that enable the establishment and development of one's analysis. 


\section{CONCLUSION}

This work represents the elaborations on the topic of demand in the transference and what can possibly be involved in it with special attention to the analytic experience.

In elaborating the theme of demand in the transference, it was indispensible to make references to the place of desire. The place of desire is intertwined with the place of demand, in a sense that the advent of desire is owing to the frustration of the primal demand in the subject's life. Hence, it is clear that the establishment of desire is due to the experience of demand. Therefore, the importance of experiencing demand in one's life as well as in the analytic setting is fundamental to have desire functioning.

My research on the place of demand in the transference shows the establishment of demand in the analytic situation, taking into account the position of subject as object of the Other's desire in the wake of castration. Thus, the process of castration consists in the effacement of the subject by the action of the signifier of the paternal metaphor, making him barred or divided in his condition of desiring subject. This division creates a tension and certain impasses that are part of the subject's dependency on the Other's desire and alienation in relation to the "lost object".

Hence, the impasses that the neurotic presents as a divided subject, are above all the impasses of his desire once his desire is not only dependent on the Other's desire, but also an effect of the demand of the Other (mother). Besides that, the first demand of the subject to be the object of the Other's desire, that has been repressed, is always renewed through the signifiers that represent it. These signifiers that represent the primal demand come up in accordance with the circuits that have been made for the advent of desire. It means that the cycle of need-demand-frustration is activated once the metonymic object, which is the "lost object", runs symbolically beneath all forms of demand. Hence, the sanction of demand and its subsequent effects are what give structure to desire.

Therefore, the structure of the neurotic reveals that his desire is not his own since it comes from the Other. However, he is implicated in this symbolic detour, in a sense that he situates himself as a subject subjected to the Other's desire and to the "lost object". In subjectifying his position regarding the desire of the Other and the "lost object", he should assume this desire as his own once it takes the symbols given by him. In doing so, the subject becomes aware of the demands he displays in the analysis and what he is in relation to these demands. However, it is essential that the 
analytic discourse leads the subject to relate his unconscious material, the signifiers of demand and sexual reality, to the manifestation of the drives in order to understand the path of his desire. Otherwise, the drives will remain unsymbolized interfering in the subject's functioning and, consequently, the subject will not be able to posit himself in relation to his desire.

I presented above a summarized trajectory of my dissertation. I would like to conclude by saying that writing this dissertation was an opportunity to develop a theme of great interest to me due to its relevance in the psychoanalytic practice. Besides that, it made me think about the place of demand in child analysis. I suppose it is important to raise the question of demand in the transference with respect to child psychoanalysis, as the child's parents are directly involved in the request for their child's analysis. Thus, it is interesting to elaborate how demand is instituted in this case and how it operates in the psychoanalytic situation. That is, in what extent there is demand from the part of the child and how it works in the analysis. I believe that the place of demand in the transference in child analysis is a very intriguing issue and deserves a lot of research. It is something that I intend to investigate and write about in future studies. 


\section{REFERÊNCIAS}

FREUD, S. (1909). Family Romances. The Standard Edition of the Complete Psychological Works of Sigmund Freud, Volume IX (1906-1908): Jensen's 'Gradiva' and Other Works, 235242.

. (1912). The Dynamics of Transference, The Standard Edition of the Complete Psychological Works of Sigmund Freud, Volume XII (1911-1913): 97 - 108, The Hoggard Press, London, 2001.

. (1918). From the History of an Infantile Neurosis, The Standard Edition of the Complete Psychological Works of Sigmund Freud, Volume XVII (1917-1919): An Infantile Neurosis and Other Works, 1-124, The Hoggard Press, London, 2001.

. (1920). Beyond the Pleasure Principle, The Standard Edition of the Complete Psychological Works of Sigmund Freud, Volume XVIII (1920-1922): 3 - 64, The Hoggard Press, London, 2001.

LACAN, J. (1951). Presentation on Transference. In Jacques Lacan. Écrits, trans. Bruce Fink, pp.176-185. Norton, 2006.

. (1953).The Function and Field of Speech and Language in Psychoanalysis. In Jacques Lacan. Écrits, trans. Bruce Fink, pp.671-702. Norton, 2006.

. (1955).Variations on the Standard Treatment. In Jacques Lacan. Écrits, trans. Bruce Fink, pp.269-302. Norton, 2006.

. (1958a). The Direction of the Treatment and the Principles of Its Power. In Jacques Lacan. Écrits, trans. Bruce Fink, pp.489-542. Norton, 2006.

. (1958b). The Signification of the Phallus. In Jacques Lacan. Écrits, trans. Bruce Fink, pp.575-584. Norton, 2006.

$\overline{\text { unpublished. }}$

(1959). Desire and its Interpretations. Book VI. Trans. Cormac Gallagher

(1960a). The Subversion of the Subject and the Dialectic of Desire in the Freudian

Unconscious. In Jacques Lacan. Écrits, trans. Bruce Fink, pp.671-702. Norton, 2006.

London, Routledge.

(1960b). The Ethics of Psychoanalysis. Book VII, trans. Dennis Porter 1992.

. (1961). Transference. Book VIII. Trans. Cormac Gallagher unpublished.

. (1962). Identification. Book IX. Trans. Cormac Gallagher unpublished.

. (1964a). The Four Fundamental Concepts of Psycho-Analysis. Book XI, trans. Alan Sheridan 1977. London, The Hogarth Press Ltd.

. (1964b). On Freud's "Trieb" and the Psychoanalyst's Desire. In Jacques Lacan. Écrits, trans. Bruce Fink, pp.722-725. Norton, 2006.

$\overline{\text { unpublished. }}$

. (1966a). The Object of Psychoanalysis. Book XIII. Trans. Cormac Gallagher

(1966b). On the Subject Who Is Finally in Question. In Jacques Lacan. Écrits, trans. Bruce Fink, pp.189-196. Norton, 2006.

. (1970). The Other Side of Psychoanalysis. Book XVII, trans. Russell Grigg 2007.

London, W. W. Norton \& Company, Inc. 
(1973). On Feminine Sexuality: The Limits of Love and Knowledge, Encore, trans. Book XX. Bruce Fink 1999. London, W. W. Norton \& Company, Inc.

SAUSSURE, F. (1907-1911). Course in general linguistics; edited by Charles Bally and Albert Sechehaye; with the collaboration of Albert Riedlinger; translated and annotated by Roy Harris. London: Duckworth, 1983. 


\section{As Nuances da Demanda no Discurso Analítico: Uma Perspectiva lacaniana}

\section{Resumo}

Esse artigo examina o estabelecimento da demanda do analisando na experiência analítica, considerando a sua posição de sujeito desejante como efeito do processo de castração. Esse trabalho tem como objetivo investigar o lugar da demanda na transferência através de aspectos relevantes para o trabalho clínico, tais como os manejos do analista no desenrolar da análise. Dessa forma, a autora investiga as elaborações de Lacan sobre o conceito de transferência e sua aplicabilidade na clínica psicanalítica.

PALAVRAS-CHAVE: Demanda. Sujeito Desejante. Transferência. Lacan. Clínica Psicanalítica. 


\section{Les Nuances de la Demande dans le Discours Analytique : Une Perspective LacanienNe}

\section{RÉSUMÉ}

Cet article examine la demande du patient dans l'expérience analytique, en tenant compte de leur position sujet désirant comme un effet de processus de castration. II vise à examiner la place de la demande dans le transfert en considérant des aspects pertinents au travail clinique, tels que les manœuvres de l'analyste dans le développement de son analyse. Par conséquent, l'auteur étudie les élaborations de Lacan sur le concept du transfert et de son application dans la clinique psychanalytique.

MOTS-CLÉS: La Demande. Sujet Désirant. Transférer. Lacan. Clinique Psychanalytique. 
The Nuances of Demand in The Analytic Discourse: A Lacanian Perspective

Recebido em: 02-06-2018

Aprovado em: 15-06-2018

(C) 2018 Psicanálise \& Barroco em revista

http://www.seer.unirio.br/index.php/psicanalise-barroco/index

revista@psicanaliseebarroco.pro.br

Programa de Pós-Graduação em Memória Social — UNIRIO.

Memória, Subjetividade e Criação.

http://www.memoriasocial.pro.br/proposta-area.php

212 Psicanálise \& Barroco em revista | v.16, n. 01 | julho de 2018 